\title{
2005년 필리핀 개발포럼 및 제26차 필리핀 원조공여국 회의 결과
}

3월 7 8일간 Davao市에서 필리핀 정부와 World Bank 공동 주최로 필리핀 정부인사, 원조공여국 및 국제기구대표 250 명이 참석한 가운데 표제회의가 개 최된 바, 회의의 주요내용은 다음과 같음.

\section{I . 핵심사항}

밀리핀 정부는 작년 Arroyo 대통령의 재집권이래 추진해 온 10대 공약(10-Point Agenda) 및 중기 개발계획(Mid-Term Philippine Development Program)을 중심으로 각종 개혁조치를 소개하고 이에 대한 원조공여국/국제기구측의 적극적인 협 조를 당부했으며 원조공여국들은 개혁을 신속하 고 철저히 추진함으로써 경제발전과 빈곤타파을 위한 선순환을 이끌어낼 것을 주문하였음.

ㅁ유명환 주필리핀 대사는 우리의 ⿶ㅝㅇ필리핀 ODA 현 황과 다바오직업훈련원 개원식을 소개하고 필리
핀 경제발전과 인적자원 개발을 위한 우리 정부의 지원의지를 표명하였음.

\section{II. 회의개요}

\section{1. 회의제목}

口 2005 Philippines Development Forum:a Meeting of the Philippines Consultative Group \& other Stakeholder

\section{2. 참석자(약 250명)}

ㅁ필리핀정부:대통령, 재무부, 경제개발청, 통상산 업부, 에너지부, 교통통산부, 민다나오개발청, 농 업부 등 경제부처 장관 전원 및 하원의원 수 명

ㅁ 원조공여국/국제기구

- 미국, 일본, 호주, 뉴질랜드, 영국, 독일 등 24 개국

-World Bank, IMF, $\mathrm{ADB}, \mathrm{EU}, \mathrm{UN}$ 등 22개 
국제기구

※ 우리 대표단은 유명환 대사, 배한진 서기관, 최성호 $\mathrm{KOICA}$ 소장이 참석

\section{III. 주요 논의내용}

\section{1. 회의 전반}

믐번 회의에서 필리핀측은 Arroyo 대통령을 비롯 한 경제각료 전원이 참석하여 10 대 공약 및 중기 발전계획에 따른 필리핀 정부의 개혁 노력을 소개 하고 문제점과 개선책에 관한 원조공여국들의 의 견을 청취하여 이를 정책에 반영하겠다는 의지를 천명하였음.

-(1)VAT 인상, $\operatorname{Sin} \operatorname{Tax}$ 등의 증세조치, 전력공사 등 적자 국영기업 매각 등 재정적자 해소를 위한 개혁조치 (2)투자 유치노력 (3)부패, 무능 해소를 통한 good governance 육성 (4)교육, 보건 강화

(5)지방별 균형발전 방안 등을 소개

ㅁ원조공여국 대표들은 필리핀 정부의 개혁조치와 관련, 작년도 경제실적 호조(6.1\% 성장) 및 세계경 제 호조와는 달리 기회의 창이 줄어들고 있으므로 (narrowing the windows of opportunity) 실기 (失機)하지 않기 위해서는 개혁조치를 신속하고 철 저히 추진해야 한다고 강조함.

-아울러 각종 개혁조치에 대한 경과 및 미비사 항을 세세히 지적하고 이에 대한 시정계획을 주문함.

ㅁㅣㅣㄹ리핀의 정치, 경제, 사회 발전은 빈곤층과 소외
지역의 통합, 재정적자 해소, 부패무능 타파, 인구 문제 해결 등의 종합적이고 동시다발적인 노력이 필요한 것임이 재차 확인됨.

-아울러 필리핀 전체의 정치안정과 경제발전을 위해서는 낙후지역인 민다나오의 평화 정착과 경제개발을 통해 동 지역의 치안 불안을 해소하 고 주류사회에 편입시키는 노력이 필수적임.

\section{2. 주요인사 언급 요지}

\section{1) Arroyo 대통령(폐막연설)}

ㅁ작년도 대통령선거 이래 강력한 개혁조치를 추진 함으로써 많은 성과를 얻을 수 있었는 바, 정치적 안정, 민다나오의 평화질서 회복, 투자유치에 유 리한 대법원 판결, 재정개혁에 대한 의회의 협조 등이 중요한 사례가 되고 있음.

ㅁ재정개혁조치로 조세행정개혁, 국영기업 사유화, 예산적자 해소 및 빈곤타파조치 등을 추진하고 있 는 바, 돈세탁 방지 비협조국 명단 제외, 일부 신용 평가기관의 등급 상향 조정, 페소화 강세 등의 좋 은 징조가 나오고 있음.

ㅁ 경제개발을 위해 콜센터, 하이테크분야, 자동차산 업에 대한 해외투자유치를 희망하고 있으며 중소 기업, 농업, 주택, 광업 등의 육성 및 클라크-수빅 개발 등을 통해 천만 개의 일자리를 창출하고자 노 력하고 있음.

ㅁ 대외정책과 관련하여서는 영토보존과 해외파견근 로자 보호라는 대전제 하에 기존 우방국인 미국 및 아세안 제국 등과의 전략적 동맹을 강화하고 이슬 람권, $\mathrm{EU}$ 등과의 파트너십을 육성해 나갈 것임. 


\section{2) Von Amsberg 세계은행 지역대표}

ㅁ최근 세계경제의 침체 조짐 및 국제이자율 인상 등 을 감안할 때, 경제개발을 위한 기회의 창이 점차 줄어들고 있으므로 경제개혁조치의 시급함이 강 조되고 있음.

뫼근 전력요금 인상, 주류, 담배세 부과, 재정건정 성 확보 프로그램 도입, 에너지분야 개혁조치 등 필리핀 정부의 개혁의지를 평가하나, 막대한 부채 누적으로 인한 원리금 상환 부담이 경제발전의 최 대의 걸림돌임을 감안할 때, 재정개혁의 강력한 추 진이 필요함.

ㅁ재정개혁 조치로서 세원발굴뿐만 아니라 조세행 정 개선 및 정부지출시 지출책임제도 등을 중점적 으로 추진하여야 하며 현재 논의되고 있는 부가가 치세(VAT) 인상은 여러 단계의 복잡한 세제를 설 정하는 것보다는 단순한 세제를 설정하는 방안이 바람직할 것으로 보임.

묵ㄱ제사회는 필리핀의 개혁의지와 실천노력을 주 시하고 있으며 가시적인 성과가 나오는 경우 보다 많은 원조를 제공할 준비가 되어있음.

\section{3. 전체회의 및 분야별 회의}

금번 회의는 전체회의 시간을 줄이고 5 개 분야별 로 working group 회의를 개최함으로써 개개 사안 에 대한 심층적인 토론을 유도하였으며 필리핀 정부 및 공여국/국제기구 외에 NGO 및 경제계 인사 등 이해관계자들을 초청하여 다양한 의견을 수렴할 수 있도록 회의 형식을 변경함.

\section{1) 전체회의}

ㅁ전체회의에서는 필리핀 경제현황 및 개혁추진현 황과 관련하여 (1)재정개혁 및 금융제도 정비 (2)중 기개발계획에 대한 설명이 있었음.

아울러 민다나오 평화회담 및 개발계획에 관한 브 리핑이 있었음.

\section{2) 그룹별 회의}

므급ㅂㅂ별 회의는 Social Progress, Growth and Investment Climate, Economic and Fiscal Reforms, Governance, Decentralization and Local Government 등 5 개 그룹으로 나뉘어 각 분야별 현황을 점검하고 발전방안을 모색하였음.

\section{$\mathrm{IV}$. 참가 성과}

ㅁㅡㅡㅁ번 회의에서는 주재국의 경제현황, 중장기 발 전계획, 국제사회의 평가 및 향후 정책방향에 대 한 전반적인 토의가 이루어진 바, 이를 통해 우 리의 원조방향을 점검하는 좋은 계기가 된 것으 로 평가됨.

-향후 뵝필리핀 원조는 필리핀이 당면한 정치 경제 · 사회 전반에 대한 문제 해결을 위해 주재 국이 중장기적으로 설정한 개발계획 및 목표에 부합하는지 여부와 효과적인 시행가능 여부 등 종합적인 판단을 통해 결정되어야 할 것임.

-이를 위해서는 원조예상성과분석, 프로젝트 추 진방안 및 일정에 대한 점검, 사후관리에 대한 
모니터링 등을 철저히 해야 할 것이며 이를 위해 다른 공여국 및 국제기구 등과의 정보 및 의견교 환 등의 공조를 강화해야 할 것임.

-아울러 World Bank 주도의 민다나오 다자신탁 기금에도 참여하는 방안을 적극 검토할 필요가 있음.

[자료:주필리핀 대사관] 